"Assessment of the consumer purchase intentions of organic food at the Hazel food market in Pretoria, South Africa"

\begin{tabular}{|c|c|c|}
\hline AUTHORS & \multicolumn{2}{|c|}{$\begin{array}{l}\text { Vinessa Naidoo (D https://orcid.org/0000-0002-2358-5588 } \\
\text { Makate Henry Ramatsetse }\end{array}$} \\
\hline ARTICLE INFO & \multicolumn{2}{|c|}{$\begin{array}{l}\text { Vinessa Naidoo and Makate Henry Ramatsetse (2016). Assessment of the } \\
\text { consumer purchase intentions of organic food at the Hazel food market in } \\
\text { Pretoria, South Africa. Environmental Economics, 7(3), 81-88. } \\
\text { doi:10.21511/ee.07(3).2016.10 }\end{array}$} \\
\hline DOI & \multicolumn{2}{|c|}{ http://dx.doi.org/10.21511/ee.07(3).2016.10 } \\
\hline RELEASED ON & \multicolumn{2}{|l|}{ Friday, 21 October 2016} \\
\hline JOURNAL & \multicolumn{2}{|l|}{ "Environmental Economics" } \\
\hline FOUNDER & \multicolumn{2}{|c|}{ LLC "Consulting Publishing Company "Business Perspectives" } \\
\hline$\sigma^{\infty}$ & 15 & 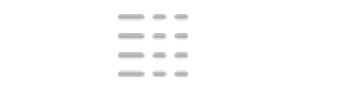 \\
\hline NUMBER OF REFERENCES & NUMBER OF FIGURES & NUMBER OF TABLES \\
\hline 0 & 0 & 0 \\
\hline
\end{tabular}

(C) The author(s) 2023. This publication is an open access article. 
Vinessa Naidoo (South Africa), Makate Henry Ramatsetse (South Africa)

\title{
Assessment of the consumer purchase intentions of organic food at the Hazel food market in Pretoria, South Africa
}

\begin{abstract}
This study on environmental economics has noticed that a growing concern for healthy food and environmentally friendly production has resulted in increased attention towards organic food. In South Africa, the market for organic food is still in the infancy stage. Food marketers continue to grapple in designing marketing campaigns to attract organic food consumers. Using a survey method, self-completed questionnaires were collected from customers aged 18 and above, by means of convenience sampling technique from a sample of 120 customers at the Hazel food market (HFM) in Pretoria. A total of 118 questionnaires were received back. STATA software was used to analyze the data. This is a quantitative study in which data analysis consisted of descriptive statistics, the Chi-square test and reliability analysis. The results suggested that customers at HFM have the intention to purchase organic food. The major findings of the study indicated that factors such as consumer values, attitude, subjective norm and perceived behavioral control significantly influence consumer's intention to purchase organic food. This study intends to provide valuable insights into current studies of consumer behavior towards organic food in South Africa. Potential beneficiaries of this research study include consumers, vendors and government agencies.
\end{abstract}

Keywords: environmental economics, consumer purchase intention, theory of planned behavior, organic food.

JEL Classification: Q5, M31.

\section{Introduction}

Over the last decade, organic food sales in the world have experienced an increase and it is predicted that the growth will continue in the coming years. A majority of sales are generated in Europe and North America which constitute over 90 percent of global sales. Although Africa is among the important producers of organic agricultural crops, it's market for organic products remains small (Willer \& Lernoud, 2015, p. 26).

Organic farming has expanded enormously over the last decades. South Africa is among the countries in the world that support organic agriculture. The country is in a process of drafting regulations on organic agriculture. South Africa does not yet have a national legislation, but it has developed a national standard on organic agriculture. In order for the country to achieve economic and financial benefits in the organic food market, it is important to understand the factors that will influence consumer's intention towards organic food purchase.

Regardless of rapid growth and the prospects of development in the organic food industry, sales of organic food in the South African food markets are relatively low compared to other countries. South Africa is yet to realize a significant mass of customers purchasing organic food. Research studies examining the predictor variables of organic food purchase intention were undertaken in various countries and have provided inconsistent and, at times, contradictory

(C) Vinessa Naidoo, Makate Henry Ramatsetse, 2016.

Vinessa Naidoo, Dr., Tshwane University of Technology, South Africa. Makate Henry Ramatsetse, Tshwane University of Technology, South Africa. findings. South Africa has few published research studies focusing on consumer purchase intention of organic food. In the absence of this marketing information, organic marketers experience difficulty in designing a strategy about the most important determinants of organic food purchase. Therefore, this study investigates the determinants of intention to purchase organic food. It was conducted at the Hazel food market, in Pretoria, South Africa.

\section{Literature review}

1.1. Concept of organic food. Since the 1920s, the world had to deal with health and environmental problems because of conventional agricultural methods. Such methods are heavily dependent on chemical pesticides, fertilizers, antibiotics and growth hormones that are assumed to be harmful to human health, as well as the environment (Vogt, 2007). In response to the problems, the society and politicians began an organic food movement pressurising businesses towards organic food adoption (Nasir \& Karakaya, 2013, p. 1).

The Soil Association (2015) defines organic food as "food produced using environmentally and animal friendly farming methods on organic farms". It further states that organic farming values the link between health and the manner in which food is produced. Organic food is produced in accordance with rules and regulations that define how an organic product is made, and the sales thereof are strictly regulated. Natural growth is encouraged, and artificial fertilizers are prohibited. Farmers create fertile soil by rotating crops and using compost and manure. Organic farming is a production system that sustains the health of the soil, ecosystems and people. Organic animals are 
allowed extensive locomotion to fields and sunlight rather than being kept indoors. According to Eloff (2014), organic food is produced without the use of chemical fertilzers or other artificial chemicals. He further states that only foods that are grown and processed according to organic standards can be labelled organic. Organic food depends on ecological processes, biodiversity and cycles adapted to local conditions, rather than the use of inputs with negative effects (IFOAM, 2014).

According to Brodie (2014), organic products are certified with a label or sticker. Food and Agriculture Organization of the United Nations (2015) (FAO) explains that certified organic products are those which have been produced, stored, processed, handled and marketed in accordance with distinct technical specifications (standards) and certified as organic by a certification body. When compliance with organic standards is confirmed by a certification body, the product can be labelled as organic. Organic labels in the world are different, but they all provide an assurance that the product is produced in accordance with all necessary organic farming processes, i.e., from the farm to the market. The organic label also provides an assurance that the product has been produced and processed using environmentally friendly methods. Hence, FAO considers that an organic label represents the production process in contrast to the product quality.

Organic agriculture has an important role to play in addressing food insecurity, land degradation, poverty and climate change in Africa. The International Federation of Organic Agriculture Movements (IFOAM) is currently working with the African organic sector, the African Union and other agencies to facilitate the integration of organic agriculture into the core of African policies and the agricultural development agenda (Willer \& Lernoud, 2015, p. 26).

In South Africa, the Department of Agriculture, Forestry and Fisheries developed a draft policy document on organic production to guide the public and private sectors on environmental and sustainability issues and to support the development of the organic sector (Department of Agriculture Forestry \& Fisheries). The South African government was compelled to develop and to implement the policy on organic farming for environmental and health benefits, as explained in the policy document.

1.1.1. Environmental benefits. Organic production improves the soil and saves water. Chemical fertilzers, pesticides and genetically modified organisms are not allowed in organic production. Pests are controlled naturally to avoid the contamination of the underground water reserves. Many lakes, rivers and other bodies of water are facing problems of getting contaminated. By using waste residues for compost and by reviving soil fertility through good farming practices, organic productions contribute to better water management practices and the preservation of a unique and vulnerably delicate biodiversity. It is also important, in this case, to consider the effectiveness of the environmental consciousness which refers to specific psychological factors (beliefs, values, attitudes) related to individuals' propensity to engage in pro-environmental behaviors (Sanchez \& Lafuente, 2010, p. 738). Kriwy and Mecking (2012, p. 31) investigated the importance of perceived environmental consciousness of organic food purchases in relation to consumer attitudes and selfreported purchase of organic food in Sweden. Environmental concerns were the most important predictors of attitude and purchase intention for organically produced food. According to a study by Lea and Worsley (2005, p. 864), 70 percent of participants agreed that organic foods are better for the environment than conventionally grown foods, ranking third among the organic belief items. Pivato et al. (2008, p. 7) concluded that organic products involve not only health or safety considerations, but also consumers' environmental conscience. A large body of literature relating to organic food consumption indicates that consumer values are important in impacting consumer attitudes of organic foods (Nasir \& Karakaya, 2014, p. 264).

"The attitude towards behavior refers to an extent to which a person has a favorable or unfavorable evaluation or appraisal of the consequences of the behavior in question" (Magnusson, Arvola, Aberg \& Sjoden, 2001, p. 213). In the past years, a growing number of people have developed adverse attitudes towards the use of artificial chemicals in agriculture (Beharrel \& MacFie, 1991, p. 25). Environmentally friendly products are gaining popularity among consumers, because they are more aware about their health and protection of the environment (Paul \& Rana, 2012, p. 412). As a result, consumers perceive food labelled as organic to be healthier, environmentally friendly and of superior quality to conventional food. A high consciousness to health and the environment leads to a more positive attitude towards organic food (Irianto, 2015, p. 23).

Previous studies show that casualty flows from values through attitude to intention, forming a hierarchical relationship of value-attitude-intention (Chen, 2009, p. 167). This means that values have an impact on attitudes which, in turn, influences a person's purchase intention. According to the author, values about health and the environment are believed to be determinants of consumer's attitude toward organic foods.

1.1.2. Health benefits. Some of the additives in foodstuffs may have a negative effect on human 
health, such as hydrogenated fats which can increase the risk of heart disease; phosphoric acid used in fertilzers can deplete calcium in bones; Mono Sodium Glutamate (MSG) used as a food additive to enhance flavor can cause dizziness, headache and asthma. Pesticides also have the potential to cause undesirable side effects. These include adverse effects on workers, consumers, community health and safety, groundwater, surface waters and nontarget wildlife organisms. In addition, the use of pesticides raises concerns about the persistence and accumulation in food chains quite distant from the original point of use. There are also concerns about the role of certain pesticides in causing reproductive failure and hormonal system abnormalities in both wildlife and humans and other species that are not the intended target.

The livestock are regularly injected with or fed antibiotic drugs to prevent disease and hormones to promote growth. There is a concern that humans are developing resistance to antibiotics due to the indirect consumption of antibiotic drug residues in animal-based products. Many of the hormones are known to mimic human hormones, leading to hormonal disruption amongst other negative impacts. Organic production systems are designed to respect the natural integrity in the relationships between the environment, health, biodiversity and the biotic community, humans being part of the family.

Large numbers of the South African population can benefit from eating more nutritious organic food which will also reduce the drain on the national healthcare system and have a positive impact on the cost of health.

\section{Research methodology}

In this study, a sample survey using the questionnaire was the method for collecting primary data in order to fulfil the goal, since it is the most effective in descriptive research to collect responses from a large sample prior to quantitative analysis. The questionnaires were answered without the interviewer being present to eliminate the potential biases, as the author would not have direct communication with the respondents.

\section{Research findings}

A sample of 120 customers was chosen to participate in the survey. Of the 120 distributed questionnaires, 118 were fully completed and returned. This represents a response rate of 98 percent. The questionnaire consisted of three sections and on average, took the respondents about fifteen minutes to complete. The first section posed questions on demographic information such as gender, age, income and education and this served to establish a profile of the sampled group. The second section consisted of questions on the consumers' past purchase experience of organic food and the last section included questions on their intention to purchase organic food based on the adopted theoretical framework.

Table 1. Reliability for each variable

\begin{tabular}{|l|l|l|}
\hline \multicolumn{3}{|c|}{ Reliability statistics } \\
\hline \multicolumn{1}{|c|}{ Variable } & \multicolumn{1}{|c|}{ Variable } & \multicolumn{1}{c|}{ Variable } \\
\hline Health consciousness & $\begin{array}{l}\text { Health } \\
\text { consciousness }\end{array}$ & $\begin{array}{l}\text { Health } \\
\text { consciousness }\end{array}$ \\
\hline Environmental consciousness & $\begin{array}{l}\text { Environmental } \\
\text { consciousness }\end{array}$ & $\begin{array}{l}\text { Environmental } \\
\text { consciousness }\end{array}$ \\
\hline Attitude & Attitude & Attitude \\
\hline Subjective norms & Subjective norms & Subjective norms \\
\hline Perceived behavioral control & $\begin{array}{l}\text { Perceived } \\
\text { behavioral control }\end{array}$ & $\begin{array}{l}\text { Perceived } \\
\text { behavioral control }\end{array}$ \\
\hline Purchase intentions & $\begin{array}{l}\text { Purchase } \\
\text { intentions }\end{array}$ & Purchase intentions \\
\hline
\end{tabular}

After having established the reliability of the questionnaire, further analysis of the descriptive statistical findings and testing for relationships, as described in the following section, were conducted.

3.1. Inferential statistical analysis. Inferential statistical analysis was conducted using the covariance analysis and Chi-square test of association determining the relations between continuous and categorical variables, respectively. The value of the coefficient was used to indicate whether the variables are positively or negatively related. In other words, when one variable increases, at what rate would the other variable increase? A positive coefficient indicates a positive relationship and the converse is also true. The $p$-value was used to assess the significance of the relationship. A significant relationship is a pvalue less than 0.05 . If the $p$-value was observed to be greater than 0.05 , the relationship was found to be insignificant.

3.2. The relationship between consumer values and purchase intention. The first objective of the research is to investigate the relationship between consumer values, i.e., health consciousness (HC), environmental consciousness (EC) and consumer's attitude (ATT) towards organic food at the Hazel food market. To answer this objective, covariance analysis was used to examine the relationship between consumer values and purchase intention.

3.3. The relationship between health consciousness and consumer attitude. As per the research question, this can be analyzed by 
conducting a test of correlation between 'health consciousness' and 'attitude', as recorded in Table 2. The table shows that the p-value of the covariance between health consciousness and attitude is less than 0.05 . The results indicate that the covariance between health consciousness and attitude is $0.37, \mathrm{z}=3.41$ and $\mathrm{p}=0.001$. This value is actually the correlation between health and attitude. There is relatively small, but significant relationship between these two latent constructs.

Table 2. Covariance between health consciousness and attitude

\begin{tabular}{|l|c|c|c|c|c|c|}
\hline \multicolumn{7}{|c|}{ OIM } \\
\hline Standardized & Coef. & Std. Err & $\mathrm{Z}$ & $\mathrm{P}>\mathrm{z}$ & $95 \%$ conf & Interval \\
\hline $\begin{array}{l}\text { Cov (Health, } \\
\text { Attitude) }\end{array}$ & .3679441 & .1078402 & 3.41 & 0.001 & .1565813 & .579307 \\
\hline LR test of model vs. saturated: $\operatorname{chi}^{2}(53)=80.60$ & Prob $>\mathrm{chi}^{2}=0.0086$ \\
\hline
\end{tabular}

3.4. The relationship between environmental consciousness and attitude. Table 3 presents the test for correlation between environmental consciousness and attitude. The table shows that the p-value of the covariance between environmental consciousness and attitude is less than 0.05. The results indicate that the covariance between environmental consciousness and attitude is $0.63, \mathrm{z}=7.00$ and $\mathrm{p}=0.000$. This value is actually the correlation between environmental consciousness and attitude. There is relatively moderate, but significant correlation between these two latent constructs. Considering the test of correlation between the two variables 'environmental consciousness' and 'attitude towards organic food', it is clear that there is a significant relationship between the two.

Table 3. Covariance between environmental consciousness and attitude

\begin{tabular}{|l|c|c|c|c|c|c|}
\hline \multicolumn{7}{|c|}{ OIM } \\
\hline Standardized & Coef. & Std. Err. & $\mathrm{z}$ & $\mathrm{P}>\mathrm{z}$ & $95 \%$ conf & Interval \\
\hline $\begin{array}{l}\text { Cov(Environmental, } \\
\text { Attitude) }\end{array}$ & .6321068 & .090339 & 7.00 & 0.000 & .4550456 & .809168 \\
\hline LR test of model vs saturated: chi2 (53) $=95.83$, Prob $>$ chi2 $=0.0003$ \\
\hline
\end{tabular}

3.5. The relationship between attitude and purchase intention. The test of association and findings between the attitude towards organic food and purchase intention are recorded in Table 4. The table shows that the p-value is less than 0.01. The results indicate that the covariance between attitude and purchase intention is $0.37, \mathrm{z}=3.37$ and $\mathrm{p}=0.001$. This value indicates that there is relatively small but significant correlation between these two latent constructs.
Table 4. Covariance between environmental attitude and purchase intention

\begin{tabular}{|l|c|c|c|c|c|c|}
\hline \multicolumn{7}{|c|}{ OIM } \\
\hline \multicolumn{1}{|c|}{ Standardized } & Coef. & Std. Err. & $\mathrm{z}$ & $\mathrm{P}>\mathrm{z}$ & $95 \%$ conf & Interval \\
\hline $\begin{array}{l}\text { Cov (Intention, } \\
\text { Attitude) }\end{array}$ & .377846 & .1121682 & 3.37 & 0.001 & .1580004 & .5976916 \\
\hline LR test of model vs saturated: chi2 (53) $=74.81$, Prob $>$ chi2 $=0.0259$ \\
\hline
\end{tabular}

3.6. The relationship between subjective norm and purchase intention. The test of association findings between the 'subjective norm' element and the consumer purchase intention towards organic food are recorded in Table 5. The results show that the $\mathrm{p}$-value of the covariance between subjective norm and purchase intention is less than $1 \%$. The covariance is recorded at $0.41, \mathrm{z}=3.6$ and $\mathrm{p}=0.000$. Considering the coefficient of 0.41 and p-value of 0.000 , one may conclude that there is relatively small, but significant correlation between these two latent constructs.

Table 5. Covariance between subjective norm and purchase intention

\begin{tabular}{|l|c|c|c|c|c|c|}
\hline \multicolumn{7}{|c|}{ OIM } \\
\hline Standardized & Coef. & Std. Err. & $\mathrm{z}$ & $\mathrm{P}>\mathrm{z}$ & $95 \%$ conf & Interval \\
\hline $\begin{array}{l}\text { Cov (Intention, } \\
\text { SN) }\end{array}$ & .4098457 & .113809 & 3.60 & 0.000 & .1867841 & .6329074 \\
\hline LR test of model vs saturated: chir (43) $=86.64$, Prob $>$ chi² $=0.0001$ \\
\hline
\end{tabular}

3.7. The relationship between perceived behavioral control and purchase intention. The test of association findings between the 'perceived behavioral control' and intention towards organic food is recorded in Table 6. The p-value of the covariance between perceived behavioral control and purchase intention is less than $1 \%$. The results indicate that the covariance between perceived behavioral control and purchase intention is 0.62 , $\mathrm{z}=7.62$ and $\mathrm{p}=0.000$. Considering the coefficient of 0.41 and $p$-value of 0.000 , one may conclude that there is moderate, but significant correlation between these two latent constructs.

Table 6. Covariance between perceived behavioral control and purchase intention

\begin{tabular}{|l|c|c|c|c|c|c|}
\hline \multicolumn{7}{|c|}{ OIM } \\
\hline Standardized & Coef. & Std. Err. & $\mathrm{z}$ & $\mathrm{P}>\mathrm{z}$ & $95 \%$ conf & Interval \\
\hline $\begin{array}{l}\text { Cov } \\
\text { (Intention, } \\
\text { PBC) }\end{array}$ & .6204574 & .0814278 & 7.62 & 0.000 & .4608619 & .7800529 \\
\hline
\end{tabular}

3.8. The relationship between prior purchase experience and purchase intention. Table 7 presents the test of association between 'prior purchase' (PE1) and 'purchase intention' (PI1, PI2, PI3, PI4, PI5), indicating a significant 
association. The proportion of participants in the category 'prior purchase' to the proportion of the participants in the category 'purchase intention' is significantly different. Thus, the intention to purchase organic food is significantly associated with prior purchase ( $\mathrm{p}$-value $<0.05$ ).

Table 7. Association between prior purchase experience and purchase intention

\begin{tabular}{|c|c|c|}
\hline Item & Pearson's Chi' ${ }^{2}$ test & P-value \\
\hline PI1 & 29.5988 & 0.000 \\
\hline PI2 & 22.4436 & 0.000 \\
\hline PI3 & 15.4364 & 0.004 \\
\hline PI4 & 28.9850 & 0.000 \\
\hline PI5 & 16.5696 & 0.002 \\
\hline \multicolumn{3}{|c|}{${ }^{* *}$ Significant at Alpha $=0.05$} \\
\hline
\end{tabular}

3.9. The relationship between the number of items purchased and purchase intention. The number of items purchased (PE2) and purchase intention (PI1, PI2, PI3, PI4, PI5) are significantly associated. The proportion of participants in the category 'number of items purchased' to the proportion of the participants in the category 'purchase intention' is significantly different. Thus, intention to purchase organic food is significantly associated with number of items purchased ( $p$-value $<0.05$ ). Table 8 presents the details of these items.

Table 8. Association between the number of items purchased and purchase intention

\begin{tabular}{|c|c|c|}
\hline Item & Pearson's Chi2 test & P-value \\
\hline PI1 & 33.8112 & 0.000 \\
\hline PI2 & 41.6506 & 0.000 \\
\hline PI3 & 47.8454 & 0.000 \\
\hline PI4 & 33.6360 & 0.000 \\
\hline PI5 & 26.8216 & 0.001 \\
\hline \multicolumn{3}{|c|}{${ }^{* *}$ Significant at Alpha $=0.05$} \\
\hline
\end{tabular}

3.10. The relationship between demographic variables and purchase intention. It was observed in the survey that the intention to purchase organic food could be affected by the demographic profile of the consumers. Therefore, a $\mathrm{Chi}^{2}$ test of association was conducted to check for significant difference between the intention to purchase organic food and demographic factors.

Gender: Table 9 presents the test of association between 'gender' and 'purchase intention'. The results indicate that gender (D1) and purchase intention (PI1, PI2, PI3, PI4) are not significantly associated. That is, the proportion of males to the proportion of females in the levels of PI1, PI2, PI3 and PI4 is not significantly different ( $\mathrm{p}$-value > $0.05)$. In other words, males and females did not differ significantly with respect to their purchase intention. However, the proportion of males and females differs significantly on their level of willingness to pay more to buy organic food for the benefit of their health (PI5).

Table 9. Association between gender and purchase intention

\begin{tabular}{|c|c|c|}
\hline Item & Pearson's Chi2 test & P-value \\
\hline $\mathrm{PI} 1$ & 3.0727 & 0.546 \\
\hline $\mathrm{P} 12$ & 1.8701 & 0.76 \\
\hline $\mathrm{PI} 3$ & 3.1268 & 0.537 \\
\hline $\mathrm{PI} 4$ & 6.9215 & 0.14 \\
\hline $\mathrm{PI} 5$ & 9.7296 & 0.045 \\
\hline \multicolumn{3}{|c|}{${ }^{* *}$ Significant at Alpha $=0.05$} \\
\hline
\end{tabular}

Age: Table 10 presents the test of association between 'age' (D2) and 'purchase intention' (PI1, PI2, PI3, PI4, PI5). These items are not significantly associated. That is, the proportion of participants in the category 'age' to the proportion of the participants in the category 'purchase intention' is insignificantly different. Thus, intention to purchase organic food is insignificantly associated with age (p-value > 0.05).

Table 10. Association between age and purchase intention

\begin{tabular}{|c|c|c|}
\hline Item & Pearson's Chi' test & P-value \\
\hline PI1 & 21.7257 & 0.152 \\
\hline PI2 & 14.9917 & 0.525 \\
\hline PI3 & 22.5374 & 0.127 \\
\hline PI4 & 12.7556 & 0.691 \\
\hline PI5 & 20.4275 & 0.202 \\
\hline \multicolumn{3}{|c|}{${ }^{\text {**Significant at Alpha }=0.05}$} \\
\hline
\end{tabular}

Education: Table 11 presents the test of association between 'education' and 'purchase intention'. The level of education (D3) and purchase intention (PI1, PI2, PI3, PI4, PI5) are not significantly associated. That is, the proportion of participants in the category 'education' to the proportion of the participants in the category 'purchase intention' is insignificantly different. Thus, intention to purchase organic food is insignificantly associated with the level of education ( $p$-value > 0.05).

Table 11. Association between education and purchase intention

\begin{tabular}{|c|c|c|}
\hline Item & Pearson's Chi2 test & P-value \\
\hline PI1 & 16.8068 & 0.398 \\
\hline PI2 & 16.5635 & 0.414 \\
\hline PI3 & 13.2762 & 0.652 \\
\hline PI4 & 17.8829 & 0.331 \\
\hline PI5 & 19.0872 & 0.264 \\
\hline \multicolumn{3}{|c|}{} \\
\hline
\end{tabular}

Monthly income: The respondents gross monthly income (D4) and purchase intention (PI1, PI2, PI3, PI4, PI5) are not significantly 
associated. That is, the proportion of participants in the category 'income' to the proportion of the participants in the category 'purchase intention' is insignificantly different. The details are displayed in Table 12. Thus, intention to purchase organic food is insignificantly associated with income ( $\mathrm{p}$-value $>0.05$ ).

Table 12. Association between income and purchase intention

\begin{tabular}{|c|c|c|}
\hline Item & Pearson's Chi² test & P-value \\
\hline Pl1 & 21.3756 & 0.375 \\
\hline $\mathrm{PI} 2$ & 24.858 & 0.207 \\
\hline $\mathrm{PI} 3$ & 25.4325 & 0.185 \\
\hline PI4 & 28.7964 & 0.092 \\
\hline $\mathrm{PI} 5$ & 30.2153 & 0.066 \\
\hline \multicolumn{3}{|c|}{${ }^{* *}$ Significant at Alpha $=0.05$} \\
\hline
\end{tabular}

\section{Discussion and recommendations}

In view of the main findings provided above, the following recommendations are suggested:

\subsection{To marketers:}

a) it is important to increase an awareness of the health and environmental benefits of organically produced food to develop a positive attitude among consumers. This can be done by effective product awareness programs in the form of:

- Placing advertisements on websites.

- Social media presence through sites such as Facebook and Twitter, because they serve as forums where consumers discuss their lives, including their purchases and the items they like.

- Advertising using traditional methods such as print media (newspapers and magazines). Since organic food is perceived as healthy and environmentally friendly, advertising should also be included in health and environmental sustainability publications.

- Sponsoring public events where the name of the organic food market will be prominently displayed for potential customers.

- Displaying organic products in the market where it is easy for customers to notice;

b) marketing programs aimed at attracting organic consumers targeting the young and old, males and females, low income and high income earners and the educated and uneducated, i.e., marketing programs should not discriminate on the basis of demographics such as gender, age, education and income;

c) it is suggested that marketers may focus more on customer attraction and retention during awareness programs, as consumers intention to purchase organic food is also based on their past purchase experience.

4.2. To government and policymakers. Some respondents do not trust the quality of organic foods and perceive it as 'a fraud'. Government agencies and industry need to be aware of the necessity to continually regulate the organic food market. They also need to enhance the inspection and certification of organic food labelling, as well as ensure that the labelling and logos guarantee quality.

\subsection{To manufactures and producers}

a) consumers indicated that if organic food is available, they will buy it. Availability of organic food is a limiting factor in the food markets. An increase in the production and supply of organic food to the markets would help to raise the 'perceived behavioral control' by reducing some barriers like limited availability and accessibility on the market.

b) providing more information about the production and control processes of organic food may assist in reducing the uncertainty and may help to increase knowledge and trust and also increase the consumer purchase intention. Organic food marketing is still at an infant's stage in South Africa. There is a clear need to educate consumers regarding the differences between organic and conventional food in the market place.

\section{Conclusion}

In this study, consumer purchase intention towards organic food was investigated using a questionnaire directed to consumers at the Hazel food market. In spite of the above-mentioned limitations, this research gave an overview of consumer purchase intention towards organic food. The demographic analysis indicated that gender, age, income and level of education do not seem to have a significant influence on the purchase intention towards organic food. The results indicated that the consumer purchase intention is rather influenced by attitude, perceived behavioral control, subjective norm and past purchase experience. The consumer values of being health conscious and environmentally conscious have a significant influence on attitude. With regard to the environmental measures, respondents did care about the environment which is aligned with the finding from Lea and Worsley, (2005, p. 864). The results of this study revealed that the attitude of HFM consumers towards purchasing organic food is positively affected by their environmental consciousness. 


\section{References}

1. Beharrel, B. \& Macfie, J.H. (1991). Consumer attitudes to organic foods, British food journal, 93(2), pp. 25-30.

2. Brodie, N. (2014). SA's organics - a retail free-for-all. Available from: http://www.women24.com/News/SAsorganics-a-retail-free-for-all-20141006-2. Accessed on 11/10/2014.

3. Burns, R.B. \& Burns, R.A. (2011). Business research methods and statistics using SPSS. London: Sage.

4. Chen, M.F. (2007). Consumer attitudes and purchase intentions in relation to organic foods in Taiwan: Moderating effects of food-related personality traits, Elsevier, 18, pp. 1008-1021.

5. Chen, M. (2009). Attitude toward organic foods among Taiwanese as related to health consciousness, environmental attitudes, and the mediating effects of a healthy lifestyle, British food journal, 111(2), pp. 165-178.

6. Cooper, D.R. \& Schindler, P.S. (2006). Business research methods. New York: McGraw-Hill.

7. De Vos, A.S., Strydom, H., Fouche, C.B. \& Delport, C.S.L. (2005). Research at grass roots: For the social sciences and human service professions. 3rd ed. Pretoria: Van Schaik.

8. Eide, B. (2013). Consumer behavior theories - Purchasing organic food. Aarhus University.

9. Eloff, H. (2014). 5 things you are getting wrong about organic food. Available from: http://m.news24.com/news24/SouthAfrica/News/5-things-you-are-getting-wrong-about-organic-food-20141008. Accessed on 11/10/2014.

10. Entrepreneur's Toolkit. (2009). Organic agriculture in South Africa. Available from: http://www.entrepreneurstoolkit.org/index.php?title=Organic_agriculture_in_South_Africa. Accessed: 29/06/2015.

11. Food And Agriculture Organization Of The United Nations. (2015). What are certified organic products? Available from: http://www.fao.org/organicag/oa-faq/oa-faq2/en/._Accessed on 05/07/2015.

12. Gotschi, E., Vogel, S., Lindenthal, T. \& Larcher, M. (2010). The role of knowledge, social norms, and attitudes toward organic products and shopping behavior: Survey results from high school students in vienna, The journal of environmental education, 41(2), pp. 88-100.

13. Gracia, A. \& De Magistris, T. (2007). Organic food product purchase behaviour: a pilot study for urban consumers in the South of Italy, Spanish journal of agricultural research, 5(4), pp. 439-451.

14. IFOAM. (2014). Definition of organic agriculture. Available from: http://www.ifoam.org/en/organiclandmarks/definition-organic-agriculture. Accessed on 08/09/2014.

15. Irianto, H. (2015). Consumers' attitude and intention towards organic food purchase an extension of theory of planned behavior in gender perspective, International journal of management, economics and social sciences, 4(1), pp. 17-31

16. Kavaliauske, M. \& Ubartaite, S. (2014). Ethical behaviour: factors influencing intention to buy organic products in Lithuania, Economics and management, 19(1), pp. 72-83.

17. Kazemi, F. \& Bayat, S. (2012). The effect of integrating technology in teaching as part of teachers' PCK on students' attitude, misconceptions, and mathematical problem solving performance, International journal of education and information technologies, 6(1), pp. 1-8.

18. Kihlberg, I. \& Risvik, E. (2007). Consumers of organic foods value segments and liking of bread, Food quality and preference, 18 , pp. 471-481.

19. Kim, H.Y. \& Chung, J.E. (2011). Consumer purchase intention for organic personal care products, Journal of consumer marketing, 28(1), pp. 40-47.

20. Kriwy, P. \& Mecking, R.A. (2012). Health and environmental consciousness, costs of behaviour and the purchase of organic food, International journal of consumer studies, 36, pp. 30-37.

21. Kumar, R. (2005). Research methodology. London: Sage.

22. Lea, E. \& Worsley, T. (2005). Australians' organic food beliefs, demographics and values, British food journal, 107(11), pp. 855-869.

23. Magnusson, M.K., Arvola, A., Aberg, L. \& Sjoden, P.O. (2001). Attitudes towards organic foods among Swedish consumers, British food journal, 103(3), pp. 209-226.

24. Magnusson, M.K., Arvola, A., Hurti, U.K.K. \& Sjoden, P.O. (2003). Choice of organic foods is related to perceived consequences for human health and to environmentally friendly behaviour, Appetite, 40, pp. 109-117.

25. Malhorta, N.K. (2009). Basic marketing research: A decision making approach. New Jersey: Pearson.

26. Maree, K. (2007). First steps in research. Pretoria: Van Schaik.

27. Marian, L., Chrysochou, P., Krystallis, A. \& Thogersen, J. (2014). The role of price as a product attribute in the organic food context: An exploration based on actual purchase data, Food quality and preference, 37, pp. 52-60.

28. Mccarthy, B. \& Murphy, L. (2013). Who's buying organic food and why? Political consumerism, demographic characteristics and motivations of consumers in North Queensland, Tourism andmanagement studies, 9(1), pp. 72-79.

29. Michaelidou, N. \& Hassan, L.M. (2008). The role of health consciousness, food safety concern and ethical identity on attitudes and intentions towards organic food, International journal of consumer studies, 32, pp. 163-170.

30. Nasir, V.A. \& Karakaya, F. (2013). Underlying motivations of organic food purchase intentions, Agribusiness, (1)19.

31. Nasir, V.A. \& Karakaya, F. (2014). Consumer segments in organic foods market. Journal of consumer marketing, 31(4), pp. 263-277.

32. Newsom, J.T., Mcfarland, B.H., Huguet, N. \& Zani, B. (2005). The health consciousness myth: Implications of the near independence of major health behaviors in the North American population, Social science and medicine, 60(2), pp. 433-437. 
33. Padel, S. \& Foster, C. (2005). Exploring the gap between attitudes and behaviour: Understanding why consumers buy or do not buy organic food, British food journal, 107(8), pp. 606-625.

34. Paul, J. \& Rana, J. (2012). Consumer behaviour and purchase intention for organic food, Journal of consumer marketing, 29(6), pp. 421-422.

35. Pivato, S., Misani, N. \& Tencati, A. (2008). The impact of corporate social responsibility on consumer trust: The case of organic food, Blackwell, 17(1), pp. 1-12.

36. Recker,A.\& Saleem,B. (2014). The effects of consumer knowledge and values on attitudes and purchase intentions.M.Marketing thesis, Umeå School of Business and Economics.

37. Robinson, P. (2007). Designing and conducting mixed methods research, Australian and New Zealand journal of public health, 31(4), pp. 387-389.

38. Sahota, A. (2015). The global market for organic food and drink. Available from: www.fibl.org/fileadmin/documents/shop/1663-organic-world-2015.pdf. Accessed on 08/09/2014.

39. Samarasinghe, R. (2012). Is social psychological model sufficient:Empirical research gaps for understanding green consumer attitudinal behaviour, International journal of advanced research in management and social sciences, 1(4), pp. 28-54.

40. Sanchez, M.J. \& Lafuente, R. (2010). Defining and measuring environmental consciousness, Revista Internacional de Sociología (RIS ), 68(3), pp. 731-755.

41. SAOSA. (2015). Organic Standards [Online]. Available from: http://www.saoso.org/Organic-Standards.php. Accessed on 29/06/2015.

42. Saunders, M., Lewis, P. \& Thornhill, A. (2012). Research methods for business students. 5th ed. London: Prentice Hall.

43. Soil Association. (2015). Organic farming. Available from: http://www.soilassociation.org/whatisorganic/organicfarming. Accessed on 09/06/2015.

44. South Africa. Department of Agriculture, Forestry \& Fisheries, National policy on organic farming: Confidential discussion paper. Available from: http://www.nda.agric.za/doaDev/sideMenu/plantProduction/doc/ National\%20Policy\%20on\%20Organic\%20\%20Production\%20\%20Draft\%208.pdf. Accessed on 29/10/2014.

45. Soyes, K., Francis, J.N.P. \& Smirnova, M.M. (2012). How individual, product and situational determinants affect the intention to buy and organic food buying behavior: a cross-national comparison in five nations, International journal of marketing, 51, pp. 27-35.

46. Sriwaranun, Y., Gan, C., Lee, M. \& Cohen, D.A. (2015). Consumers' willingness to pay for organic products in Thailand, International journal of social economics, 42(5), pp. 480-510.

47. Stolz, H., Moschitz, H. \& Janssen, M. (2013). Organic certification labels from the perspective of consumers in Switzerland, Journal of socio-economics in agriculture, 1(6), pp. 225-246.

48. Suh, B.W., Eves, A. \& Lumbers, A. (2012). Consumers' attitude and understanding of organic food: The case of South Korea, Journal of foodservice business research, 15(1), pp. 49-63.

49. Tarkiainen, A. \& Sundqvist, S. (2005). Subjective norms, attitudes and intentions of Finnish consumers in buying organic food, Emerald, 107(11), pp. 808-822.

50. Tung, S.J., Shih, C.C., Wei, S. \& Chen, Y.H. (2012). Attitudinal inconsistency toward organic food in relation to purchasing intention and behavior: An illustration of Taiwan consumers, Emerald, 114(7), pp. 997-1015.

51. Urban, J., Zverinova, I. \& Scasny, M. (2012). What motivates Czech consumers to buy Organic Food, Czech sociological review, 48(3), pp. 509-536.

52. Vogt, G. (2007). Organic farming: An international history. Available from: http://ilearn.unand.ac.id/pluginfile.php/24259/mod_resource/content/1/\%5BW_Lockeretz\%5D\%20Organic\%20F arming\%20An\%20Internationa\%201History.pdf. Accessed on 09/06/2014.

53. Vongmahadlek, J. (2012). An empirical study on organic product purchasing behavior: a case study of Thailand, Journal of management, 10(2).

54. Walliman, N. (2011). Research methods: The basics. USA and CANADA: Routledge.

55. Wee, C.S., Ismail, K. \& Ishak, N. (2014). Consumers perception, purchase intention and actual purchase behavior of organic food products, Review of integrative business \& economics research, 3(2), pp. 378-397.

56. Weisberg, J., Te'eni, D. \& Arman, L. (2011). Past purchase and intention to purchase in e-commerce, Internet research, 21(1), pp. 82-96.

57. Willer, H. \& Lernoud, J. (2015). The world of organic agriculture. statistics and emerging trends. Available from: https://www.fibl.org/fileadmin/documents/shop/1663-organic-world-2015.pdf. Accessed on 28/06/2015.

58. Xie, B., Wang, L., Yang, H., Wang, Y. \& Zhang, M. (2015). Consumer perceptions and attitudes of organic food products in Eastern China, British food journal, 117(3), pp. 1105-1121.

59. Yang, M., Al-Shaaban, S. \& Nguyen, T.B. (2014). Consumer attitude and purchase intention towards organic food. Master in marketing, Sweden, Linnæus University.

60. Yin, S., Wu, L., Du, L. \& Chen, M. (2010). Consumers' purchase intention of organic food in China, J Sci Food Agric, 90, pp. 1361-1367. 